\title{
EMOTION IN IRVING KARCHMANR'S NOVEL MASTER OF THE JIN
}

\author{
${ }^{1 *}$ Dedi Darmadi, ${ }^{2}$ Purwarno, and ${ }^{3} \mathrm{M}$. Manugeren \\ 1,2,3 Master's Program, Fakultas Sastra, \\ Universitas Islam Sumatera Utara, Medan, Indonesia \\ *Corresponding author: dedidarmadi385@gmail.com
}

\begin{abstract}
The research is about the analysis of the emotion of some characters in Karchman's novel Master of the Jin. The purpose of this research to describe types of emotion shown by the main characters emotions of the character in the novel Sang Raja Jin. Feelings and emotions are generally dubbed as state existing in the individual or organism at a time. For example, a person feels sad, happy, afraid, angry or other symptoms after seeing, hearing, or feeling something. In other words, feelings and emotions are characterized as a psychological state in organisms or individuals as a result of events or circumstances experienced by the organism. (Izard, 1990). This research used qualitative descriptive method and psychology literature approach (Moleong, 2010) The source of data was derived from the novel Sang Raja Jin. The finding shows that both the positive and the negative emotions are found in the novel. The positive emotions are love and happy emotion. Meanwhile, the negative emotions were anxious, fear, anger, sad emotion.
\end{abstract}

Keywords: emotion, positive emotion, negative emotion

\section{Introduction}

This study is concerned with the types of emotion shown by the major characters of the novel Master of the Jin written by Karchmar (2004). The types of emotion which are found in the novel are anger, anxiety and fear, happiness, sadness, disgust, jeaulousy and envy, grief, and love.

Basically literary psychology gives attention to emotional conditions. The condition is related to the fun and unpleasant elements of emotion as shown by the fictional figures in the novel mentioned above. Emotions are a way of expressing feelings through behavior and deeds. The emotions experienced by humans vary greatly and the scope is very wide. This gives the fact that humans experience various events involving emotions. McDougall's theory of emotion (1910) depended on some basic biological considerations and on an attempt to distinguish between emotions and feelings and was also linked closely to motivation.

Feelings and emotions, according to Izard (1990) remind us that the most important part of Jame's theory was the view that emotion without feeling does not exist. 
However, it can be argued by the general agreement that emotions are complex reactions with high conditions and a change in physical and associated with strong feelings. Emotions are more intense than feelings and behavior changes often occur, then the relationships with the environment are sometimes disrupted.

\section{Literature Review}

\section{Emotion}

Strongman (2003: 2) explained that emotion is a daily, if not a moment by moment occurance. However, a treatise on emotion theory has to jump away temporarily from the everyday and instead begins with a consideration of what makes a good theory of emotion.

\section{Kinds of Emotion}

Strongman (2003: 133) divided emotion into anger, anxiety and fear, happiness, sadness, disgust, jealousy and envy, grief, and love. Each of these types of emotion can be further described below.

\section{a. Anger}

Anger is always included in lists of discrete emotions and it is usually categorized as negative. The likely reason for this is that it is a integral part of aggression, hostility and violence, which are so negative for society. However, the experience of anger is not always negative. Izard (1991) places it alongside disgust and contempt, describing the three emotions as often interacting in human experience.

A number of psychologist have written about anger, but none so cogently as Averill (1982) with his usual social constructionist view. In his treatise on anger, Averill not only shows that it is possible to undertake a penetrating analysis of a single emotion but also that in so doing it is possible to gain a much improved understanding of emotion in general.

Averill characterizes anger as a conflictive emotion that is biologically related to aggressive systems and to social living, symbolization and self-awareness. Psychologically, it is aimed at the correction of a perceived wrong and, socioculturally, at upholding accepted standards of conduct.

\section{b. Anxiety and Fear}

What is clear from these theories is that anxiety can only be understood by taking into account some of its cognitive aspects, particularly because a basic aspect of anxiety appears to be uncertainty. Also, it is reasonable to conclude that anxiety can be distinguished from fear in that the object of fear is 'real' or 'external' or 'known' or 'objective'.

\section{c. Happiness}

Averill (1993) considers happinesss in general and argues that ideas about it have remained obduratelyy fuzzy because its scope is so broad. He believes that it does not help to deal with more circumscribed concepts such us joy; this merely a substitution 
of the part for the whole. Furthermore, Averill and More argue that happiness defies understanding because of its depths of meaning.

\section{d. Sadness}

From Izard's (1991) differential emotions theory view, sadness is less tense than many of the other negative emotions. It is also somehow purer as an experience. It is made up downheartedness, discouragement, loneliness and isolation. Typical causes are the commonplace circumstances of everyday life, but especially those that usually involves loss. It seems to have the effect of slowing down the system and prompts reflection.

\section{e. Disgust}

Strongman (2003 : 138) stated that disgust is about rejection: rejection of what might be contaminated or might be distasteful, either physically or psychologically. At its basic level it seems to occur without cognition, although of course we also learn to be disgusted at many things. From a differential emotions perspective, Izard (1991) discusses disgust as fundamentally related to the expulsion of contaminated food, the experience of which only develops when the cognitions necessary to appreciate/ understand it have developed.

\section{f. Jealousy and envy}

Jealousy is the reaction to the threat that we might lose the affections of someone important to use and that these affections be directed toward someone else. Envy is more simply a desire to have what someone else has, whether this be a possession or a personal attribute or characteristic. So jealousy is based on the possibility of losing an existing relationship and envy is based on the possibility of possessing something that another person has. Generally, jealousy is more intense than envy.

\section{g. Grief}

It was stated by Strongman (2003: 141) that there are obvious links between sadness and grief, grief being what most people experience at some time over the loss of something highly valued, usually of course a loved person. Theoretically, the problem with grief is that, although it might be seen as a discrete emotion, it might also be seen as more than an emotion. The predominant emotion in the experience of grief is sadness, but other emotions are also generated by grief; anger, for example, and fear and shame.

\section{h. Love}

Love has a distinct place in Izard's (1991) scheme of things, but he does not characterize it as a discrete emotion. He views love as basic to the human condition, as involving strong, affectionally based social attachments, to be full of interest and joy but also to '... run the full gamut of emotions' (1991, p. 407). Like many psychologists who have written about love, Izard distinguishes between various types: love for parents, love for siblings and love in a romantic sense, for example. He views all types of love as having certain elements in common; he lists attachment, loyalty, devotion, protectiveness and nurturance. However, romantic love is special because it involves sexual expression, whereas the other types normally do not. 
Proceedings of the $1^{\text {st }}$ Annual International Conference on Language and Literature, 18-19 April 2018, Fakultas Sastra, UISU, Medan, Indonesia.

\section{Research Method}

The method of research which is used in this thesis is descriptive method. The descriptive method is used to express the problem objectively and as it should be. The motive of using this method in this research is to provide an overview of literary psychological reviews of the novel Master of the Jin written by Irving Karchmar.

Moleong (2010: 6) defines qualitative research as a study to understand phenomena experienced by the subject of research in a holistic way described in the forms of words and languages, to a specific context natural and exploit various scientific methods.

\section{Discussion}

From the novel which is chosen, that is, Master of the Jin, written by Irving Karchman, there are five kinds of emotions found and they will be discussed through this chapter. They are anger, anxiety, fear, happiness, and love. Each of these kinds of emotion can be futher discussed below.

\section{Anger}

Anger is a negative emotion arising from existence stimulation of disturbances from outside. Emotional emotion described as violent, raging, annoyed, annoyed, annoyed, offended, angry, and hostile. Angry expression usually occurs on the expression face, words, actions, and silence. Excerpts of anger on the characters in this novel is discussed as follows.

"Her father knew exactly what his son was doing. If he is angry, he will as cold as snow. But his anger quickly melted away. He did not tell me what even to his daughter about what happened. "(Karchmar, 2004: 77)

The quote illustrates the negative emotions of anger. Rebecca was angry that his nature will be silent and will not talk. Rebecca is angry but only briefly for not wanting to extend the problem. Her father knew Rebecca's nature who is angry.

\section{Anxiety}

Anxiety comes from the word restless, which means restlessness, discomfort, taste always worried, not calm, cannot be patient, anxious and so on. This anxiety occurs when people are facing obstacles or obstacles the. Emotion of anxiety when it happens constantly can become a fear. Quotes of anxiety on the characters in this novel are discussed as follows. The emotions of anxiety displayed by Ishaq's character can be found because most of the stories were written by Ishaq. Anxiety experienced by the character Ishaq can occur in a certain atmosphere and time.

"And your anxiety," he continued, as if he could read deep doubts my mind, "is your fear of it. (Karchmar, 2004: 29)

The quotation describes a negative emotion in the form of anxiety. His anxiety is continued, as if to doubt in his mind. Anxiety is the feeling of someone who is restless and his heart is not in peace, but in worry, anxiety, fear, and so on. 
Proceedings of the $1^{\text {st }}$ Annual International Conference on Language and Literature, 18-19 April 2018, Fakultas Sastra, UISU, Medan, Indonesia.

\section{Fear}

The fearful emotions of Ishaq are found in the novel this is because most of the stories are written by Ishaq. The fear experienced by Ishaq can occur in a certain atmosphere and time.

I shudder and sit, full of horror. I saw a huge light pole continue up to the sky. With my own eyes, and I swear, I saw the fire go through the hole of this building, missed into space, before finally falling back. The fire widened to the horizon, forming like a wing, while continuing decreased. Then the fire came back down to where we were different. (Karchmar, 2004: 215)

The quotation describes a negative emotion in the form of fear. He shudders and sits, full of horror. He sees a huge light pole continued up to the sky, and that is an emotion being afraid of a thing. This matter is clarified that Fear is one form of emotion that encourages individuals to stay away from something and avoiding contact with anything as much as possible.

\section{Happiness}

The happy or joyous emotions of Sheikh's are also displayed here. The happy emotions of Shaykh may have had at a certain time and place.

Right! "Replied the Shaykh. "God is the only source of happiness and sadness. He is the source of pain and medicine. The soul remembers this, like the drops of water remembering the oceans and so overlapping Unity Highest. Everything you learn on this path is none other than the contemplation of this truth, for all true knowledge comes from dhikr. We must cleanse our hearts with tears of regret, so we can reflecting the light of His grace and love. (Karchmar, 2004: 128)

The quotation describes positive emotions in the form of pleasure. We must cleanse our hearts with tears of regret, in order to reflect the light of his mercy and love, and this is a positive and loving emotion towards God. God's love for man is the result of response of human love for God. If man tries to love God, then God will repay him more than what he does.

\section{Love}

Love is a positive feeling that gives an active force in the self human being and it is the power in the form of attention and responsibility. Love makes one overcome feelings of isolation and separateness, but still allowing himself to be himself and maintain his integrity.

The young lady was named Rebecca, daughter of Professor Freeman. His age probably around 25 years. His body is tall and slim like a man dancer. He sits with his back straight and looks elegant. Hair his wavy black is his mother's legacy. Her attractive face and his tapered eyebrows make him deserve to be beautiful. But, the lines firmly on his lips showing a firm nature (Karhcmar, 2014: 46) 
The Shaykh is the leader of the Tariqa studied by Ishaq. He is called Amir Al-Haddi, known as a teacher who is wise and has a high level of spiritual charisma. He is known as qutb in his day. Qutb in this novel means spiritual leader, the highest in the spiritual position in Islam. He has shown great love towards anything and anyone.

The quotation describes a positive emotion in the form of love. From his eyes, it is seen that he really loves his father and that is a positive emotion that shows love between parents and child. This is clarified in the opinion of love between parents and children. Without expecting anything in returns both the parents and children love one another.

\section{Conclusions}

Based on the analysis of the emotional classification of the characters in the novel Sang King Jin, it can be summed up the following: positive emotions consisting of love and excitement. (1) Ishaq, the human love that Ishaq feels to Rebecca on first sight. (2) Shaykh, a love of God by encouraging people to trust and love God for life to be blessed. (3) Professor Solomon Freeman, the only child's love for Rebecca. (4) Rebecca, the child's love for the sole parent of Professor Solomon Freeman. (5) Aaron Simach, selflove with gratitude already healthy from the pain he suffered. (6) The Faqir, a love of God reminding Ishaq of the importance of remembering God all the time. Negative emotions consist of anxiety, fear, anger and hatred, and sadness. Anxiety is shown through some characters, namely (1) Ishaq, when he saw the Shaykh could control the birds to be silent. (2) Shaykh, when talking with Professor Solomon Freeman about ancient manuscripts he carries. (3) Professor Solomon Freeman, as he examined the manuscript 17 ancient containing hidden messages. (4) Rebecca, as she was anxiously abandoned by Ishaq who sought help outside. (5) Aaron Simach, as he was anxious take things that are not hers. (6) The Faqir, as he was anxious to speak about the history of his class of Jin Ifrit. (7) Ali and Ramli, as they were tracing the ruins of a mysterious big city.

\section{References}

Averill, J. R. (1982). Angerand Aggressions: An Essay on Emotion. New York: SpringerVerlag.

Averill, J. R. \& More, T. A. (1993). Happiness in M. Lewis \& J. M. Haviland (eds) Handbook of Emotion. New York: Guilford Press.

Averill, J. R. \& Nunley, (1988). Grief Ws An Emotion and As A Disease; A Social Constructionist Perspective. New York: Journal of Social Issues,

Izard, C. E. (1991). The Psychology of Emotions. New York: Free Press.

Karchmar, Irving. (2004). Master of the Jin. Sag Harbor, NY: Bay Street Press.

Moleong, J.L. (2010). Penelitian Kualitatif. Bandung: Remaja.

Strongman, K. T. (2003). The Psychology of Emotion. West Sussex: John Willey and Suns Ltd. 